\title{
Embriogenesis and larval ontogeny of the "piau-gordura", Leporinus piau (Fowler) (Pisces, Anostomidae) after induced spawning
}

\author{
Fábio Luiz Borçato ${ }^{1,3}$, Nilo Bazzoli ${ }^{1,4}$ \& Yoshimi Sato ${ }^{2}$ \\ 1 Programa de Pós-graduação em Zoologia de Vertebrados, Pontifícia Universidade Católica de Minas Gerais. Avenida Dom \\ José Gaspar 500, Coração Eucarístico, Caixa Postal 1686, 30535-610 Belo Horizonte, Minas Gerais, Brasil. \\ ${ }^{2}$ Estação de Hidrobiologia e Piscicultura de Três Marias, CODEVASF. Caixa Postal 11, 39205-000 Três Marias, Minas Gerais, \\ Brasil. \\ ${ }^{3}$ Bolsista PROBIC/PUC Minas Gerais. \\ ${ }^{4}$ Corresponding author. E-mail: bazzoli@pucminas.br
}

\begin{abstract}
Embriogenesis and larval ontogeny of the piau-gordura Leporinus piau (Fowler) (Pisces, Anostomidae) after induced spawning. Mature males and females of Leporinus piau (Fowler, 1941) were induced to reproduce through a hypophysation process. Extrusion occurred $12 \mathrm{~h}$ or 312 hours-degree after the hypophysation, at a water temperature of $26^{\circ} \mathrm{C}$. Fertilized eggs were maintained in incubators at $24^{\circ} \mathrm{C}$. Embryonic development, was evaluated using every 10 minutes, fresh egg samples which were analyzed under stereoscopic microscope. The larvae were collected at 24-hour intervals for seven days after hatching, fixed in Bouin's fluid and were submitted to routine histological techniques. The eggs of $L$. piau were slightly gray, non-adhesive and round-shaped. After $1.5 \mathrm{~h}$ the embryo was at the 64-blastomere phase and showed a wide yolk region on the vegetative pole. Within $6.25 \mathrm{~h}$, blastopore closure and the end of gastrula was observed. The differentiation of layers occurred after 7.5 $\mathrm{h}$ and hatching after $21 \mathrm{~h}$ after fertilization at $24^{\circ} \mathrm{C}$ or 504 hours-degree. During the first three days of the larvae development there was a gradual yolk sac reduction until its complete absorption on the fourth day, indicating the necessity of exogenous feeding. From the fourth to the seventh day, the final development of the heart, gill arches, swimblader, kidney, hepatopancreas, stomach and intestine were observed. The embryonic and larval development of $L$. piau were similar to other Anastomidae species.
\end{abstract}

KEY WORDS. Embryo, induced spawn, teleost fish.

RESUMO. Reprodutores de Leporinus piau (Fowler, 1941) foram submetidos à reprodução induzida por hipofisação. A extrusão ocorreu com 312 horas-grau após hipofisação, com temperatura da água a $26^{\circ} \mathrm{C}$. Os ovos, após fertilização, foram mantidos em incubadoras à temperatura de $24^{\circ} \mathrm{C}$. Para acompanhar o desenvolvimento embrionário, coletaram-se amostras de ovos em intervalos de 10 minutos até a eclosão, as quais foram analizadas ao microscópio esteroscópio. As larvas foram coletadas em intervalos de 24 h durante sete dias após a eclosão, fixadas líquido de Bouin e submetidas a técnicas histológicas de rotina. Os ovos de $L$. piau são esféricos, cinza claro e não adesivos. Após 1,5 h o embrião encontra-se na fase de 64 blastômeros e apresenta vasta região de vitelo (pólo vegetativo). Com 6,25 h observou-se o final da gástrula e o fechamento do blastóporo. A diferenciação dos folhetos foi observada com 7,5 h e a eclosão das larvas ocorreu com 21 h após a fertilização a $24^{\circ} \mathrm{C}$ ou 504 horas-grau. Durante os três primeiros dias do desenvolvimento larval observou-se que o saco vitelínico reduziu gradativamente até sua completa reabsorção no quarto dia, indicando necessidade de alimentação exógena das larvas a partir desta fase. Do quarto ao sétimo dias observou-se desenvolvimento final do coração, arcos branquiais, bexiga gasosa, rins, hepatopâncreas, estômago e intestino. O desenvolvimento embrionário e larval de $L$. piau é similar ao de outras espécies do mesmo gênero.

PALAVRAS CHAVE. Desova induzida, embrião, peixe teleósteo.

The "piau-gordura", Leporinus piau (Fowler, 1941), a medium size fish, that has found to be important to the food chain maintenance (TAVARES \& GODINHO 1994). FowlER (1950) described its occurrence only in Ceará, however, BRITSK et al. (1984) mentioned that it was also present in the São Francisco river basin. This species has been found in advanced ripening reproduc- 
tive state from November to February and its reproductive period coincides with the time of the year in which the highest values of light period, water temperature and rain fall were recorded (TAVAres \& Godinho 1994). Specimens of $L$. piau have rarely reached $25.0 \mathrm{~cm}$ in total length and $300 \mathrm{~g}$ of body weight (SATo et al. 2003). First sexual maturation, at Três Marias Reservoir, for females and males was achieved when they had reached $12.5 \mathrm{~cm}$ and $11.5 \mathrm{~cm}$ in total length, for females and males, respectively (SOARES et al. 1996).

Studies on embryonic and larval development of fish have been a great help to confirm the spawning place of the species (Nakatani et al. 2001). Moreover, they have allowed comparison between normal and altered development patterns (MejJide \& Guerreiro 2000; Morrinson et al. 2001). These studies also have had a taxonomic importance (NAKATANI et al. 2001) and aquaculture applicability, mainly in determining the moment of yolk sack absorption and mouth opening, which can be variable among species and indicating the necessity of exogenous feeding (SATO et al. 2003). Furthermore, studies on embryogenesis and larval ontogenesis have been important to the global knowledge of biology of species, primarily with relation to growth, feeding and behavioral aspects (NAKATANi et al. 2001).

This research analyzed morphological events related to embryogenesis and larval ontogenesis of L. piau after induced spawning.

\section{MATERIAL AND METHODS}

Thirty reproducing of $L$. piau were captured by professional fishermen in the São Francisco river, Três Marias region, Minas Gerais, were confined in $1.5 \times 1.5 \times 1.5 \mathrm{~m}$ aquaculture cages, which were located inside large earth tanks of $200 \mathrm{~m}^{2}$ with a mean depth of $1 \mathrm{~m}$ at the Hydrological and Hatchery Station of Três Marias, CODEVASF. Fish were fed on commercial feed, crude proteic $36 \%, 1.5-2.0 \%$ of live weigh per day, 5 days per week.

Specimens were induced to reproduction through hypophysation: a single dose of crude carp pituitary extract of 2.5$3.0 \mathrm{mg} / \mathrm{kg}$ of body weigh was used on males and two doses of $0.8 \mathrm{mg}$ and $5.0-6.0 \mathrm{mg} / \mathrm{kg}$ of body weigh was used on females (Woynarovich \& Horváth 1980). Fish were kept in reproduction tanks, with constant recirculating tap water at a temperature of $26^{\circ} \mathrm{C}$. A dry fertilization was conducted and eggs were then transferred to funnel-shaped incubators of 20 liters, which were maintained at $24^{\circ} \mathrm{C}$. Every 10 minutes, fresh egg samples were collected for observation and photographic recording under stereoscopic microscope until hatching.

After hatching, larvae samples were collected at 24hour intervals during seven days, fixed in Bouin's fluid for 812 hours and then submitted to routine histological techniques: embedded in historesin, sectioned at $4 \mu \mathrm{m}$ thickness and stained in toluidin blue-sodium borate.

\section{RESULTS}

\section{Eggs}

Eggs of L. piau were round-shaped, slightly gray and nonadhesive. Extrusion occurred $12 \mathrm{~h}$ after the second hormonal dose, at a water temperature of $26^{\circ} \mathrm{C}$, this corresponded to 312 hours-degree $\left(12 \mathrm{~h} \mathrm{x} 26^{\circ} \mathrm{C}\right)$. After fertilization it was possible to visualize the animal and vegetative poles of the eggs. The first was characterized by the presence of active nucleus and cytoplasm, whilst yolk globules gathering delimited the vegetative pole. The perivitelline space and chorion (thick membrane enveloping the egg) were also observed. The average egg diameter increased from $1347.84+49.30 \mu \mathrm{m}$ to $3074.47+96.88 \mu \mathrm{m}$ after hydratation.

\section{Embryogenesis}

The following phases were identified during embryogenesis, and in parenthesis, the respective period of time after fertilization.

Two blastomeres (35 $\mathrm{min})$ : fertilization originated the blastodisc, which after its first division formed two blastomeres.

Four, 8, 16, 32 and 64 blastomeres $(45,60,70,80,90 \mathrm{~min}$, respectively): they resulted from the second, third, fourth, fifth and sixth blastoderm mitotic divisions, respectively. At each mitotic division the size of the blastomeres decreased. The sixth division initiated on one edge of the blastoderm and ended on the opposite side, distributing blastomeres in two layers (Figs 1 and 2).

Blastula (95 $\mathrm{min}$ ): was identified by the stick-shaped blastoderm and reduced blastomere size (Figs 3 and 4).

Initial gastrula $(120 \mathrm{~min})$ : the epiboly movement (invagination of a blastula pole) began on the blastoderm, which then surrounded $1 / 3$ of the yolk region (Fig. 5).

Final gastrula/blastopore closure (375 $\mathrm{min})$ : blastoderm expanded over the yolk, leading to blastopore closure. The embryo body elongated, it was then possible to distinguish cranial and caudal regions (Figs 6 and 7).

Differentiation of embryonic layers (450 $\mathrm{min})$ : by the end of gastrula, higher cell differentiation occurred, it was then possible to identify the first somites and the embryoaxis (Figs 8 and 9).

Optical vesicle $(510 \mathrm{~min})$ : formation of the optical vesicle and simultaneous increase of the number of somite pairs was observed.

Optical calyx (630 min): appearance of the optical calyx on the cranial region of the embryo was observed (Fig. 10).

Tail release $(690 \mathrm{~min})$ : after the formation of the optical calyx, body contractions were registered, which lead to the tail begin release (Fig. 11).

Hatching (1260 min): with tail movements hatching occurred, as was verified by chorion rupture (Fig. 12).

\section{Larval ontogenesis}

Day 1 (length $4.12+0.13$ ): larvae showed transparent, non-pigmented and an elongated body. On the cranial region 

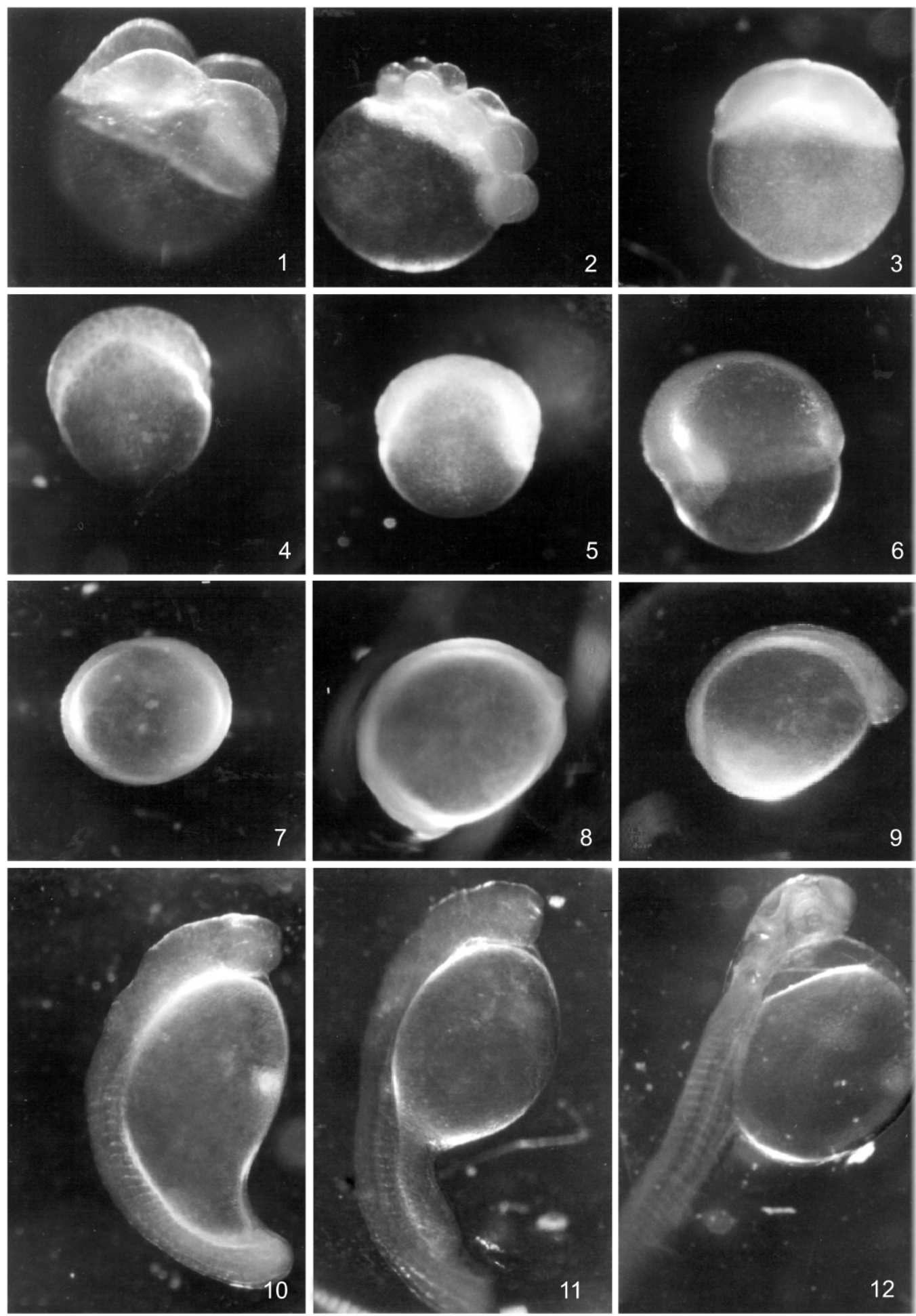

Figures 1-12. Phases of the embryonic development of L. piau: (1) four blastomeres; (2) 16 blastomeres; (3) initial blastula; (4) blastula; (5) initial gastrula; (6) gastrula; (7) blastopore closure; (8) beginning of differentiation of embryonic layers; (9) differentiation of embryonic layers; (10) formation of the optical calyx; (11) tail release; (12) hatching. 

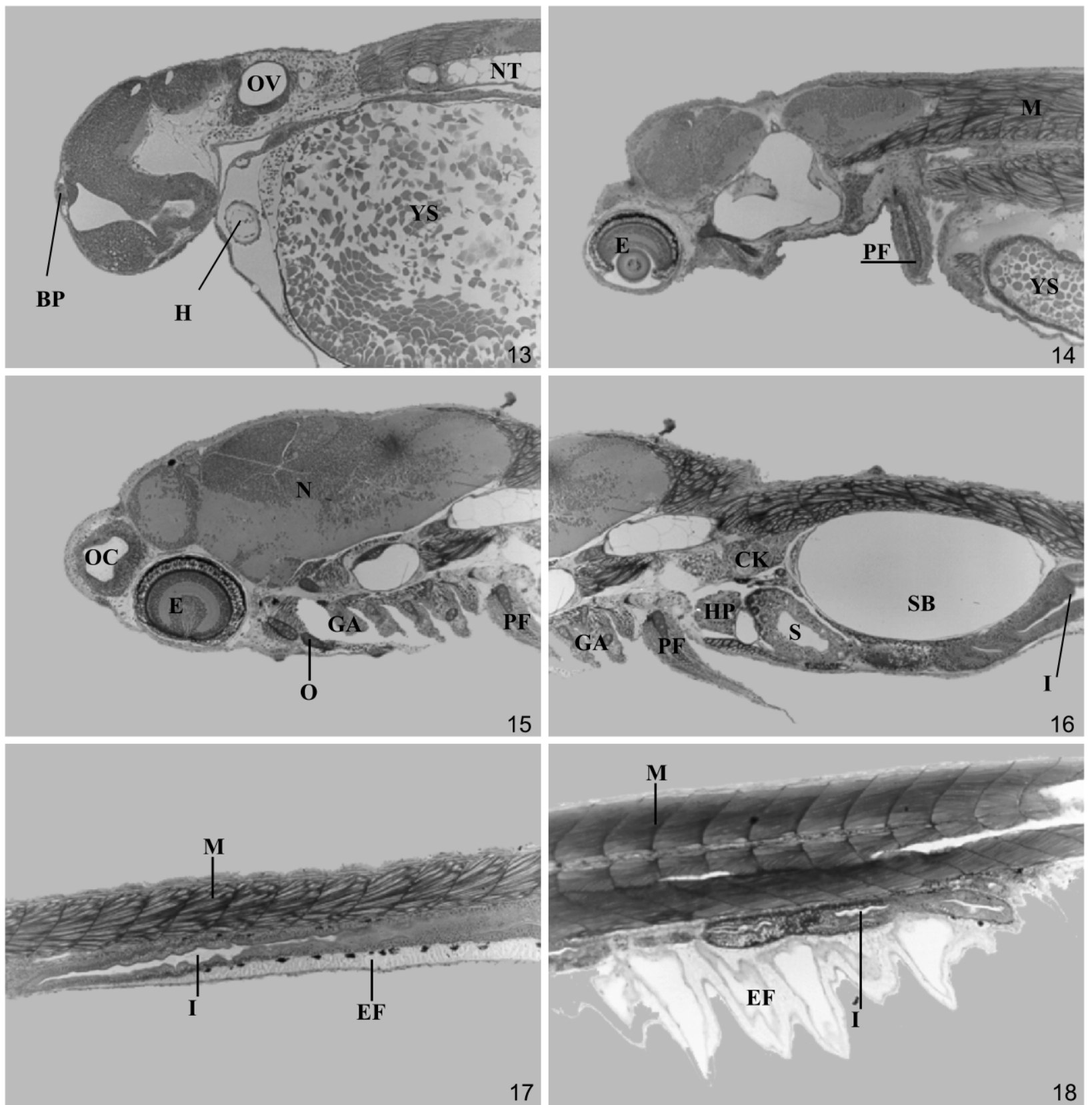

Figures 13-18. Larvae of L. piau stained in toluidin blue-sodium borate: (13) $1^{\text {st }}$ day after hatching; (14) $2^{\text {nd }}$ day after hatching; (15) $5^{\text {th }}$ day after hatching, cranial portion; (16) $5^{\text {th }}$ day after hatching, medium portion; (17) $6^{\text {th }}$ day after hatching, caudal portion; (18) $7^{\text {th }}$ day after hatching, caudal portion details. (BP) brain primordium, (CK) cranial kidney, (E) eye, (EF) embryonic fin, (GA) gill arches, (H) heart, (HP) hepatopancreas, (I) intestine, (M) miomeres, (N) neurocranium, (NT) notochord, (O) operculum, (OC) oral cavity, (OV) optical vesicle, (PF) pectoral fin, (S) stomach, (SB) swimblader, (YS) yolk sack.

was observed the head, attached to the yolk sack, brain primordium, otical vesicle, non-pigmented eye, heart containing red blood cells and wide yolk sack full of yolk globules (Fig. 13).
Day $2(4.70+0.30)$ : eye pigmentation process initiated, with chromatophores on the borders and on the retina. The head was more separated from the yolk sack, which reduced

Revista Brasileira de Zoologia 21 (1): 117-122, março 2004 
in size. The initial development of the gill arches was observed, as well as the notochord and brain vesicle on the cranial region of the body, swimblader on the medium region and approximately 33 miomeres on the caudal region (Fig. 14).

Day $3(4.97+0.19)$ : initial chondrogenesis of the neurocranium cartilages were identified as well as yolk sack reduction.

Day $4(5.34+0.14)$ : the main events were: complete absorption of the yolk sack, mouth opening, evident oral cavity, chondrogenesis of the neurocranium cartilages, and almost complete retinal pigmentation by chromatophores.

Day 5,6 and $7(5.38+0.12,5.53+0.33,5.69+0.28)$ : histological cuts on the cranial region showed: mouth, eyes with pigmented retina, gill arches, operculum, pectoral fin and neurocranium located dorsally (Fig. 15). On the medium region of the body they showed: stomach with open lumen, cranial kidney (dorsal to the stomach), hepatopancreas with hepatic portion containing hepatocytes with vesiculous nucleus and acidophyle cytoplasm, and pancreatic portion containing acinar cells with vesiculous nucleus and basal ergastoplasm. Also on the medium region were observed, intestine with open lumen, heart with red blood cells and swimblader ventrally to the notochord (Fig. 16), and on the caudal region, caudal kidney, embryonic fin, miomeres and the intestine caudal portion (Figs 17 and 18).

\section{DISCUSSION}

According to BAXTER (1988), egg size can influence species development and survival; thus, large eggs produce large larvae and frequently with higher yolk stock. Eggs of $L$. piau were smaller than the ones of other Characiformes, in spite of their vast yolk region on the vegetative pole, similar to other species of the genus Leporinus, such as Leporinus elongatus Valenciennes, 1849, Leporinus renihardti Lütken, 1874, Leporinus taeniatus Lütken, 1874 (SATo et al. 2003) and Leporinus macrocephalus (Garavello \& Britski, 1988) (Reynalte-Tataje et al. 2001).

In the present study, after fertilization, egg hydration was observed, which lead to a considerable increase of its volume. SATo et al. (2003) measured this increase in a few species of the genus Leporinus and described that eggs of L. elongatus increased approximately 5.37 times, $L$. taeniatus 11.1 times and L. piau 11.9 times.

Water temperature and turbulence have been shown to be essential during the incubation period of the eggs (Kuo et al. 1973). The eggs of L. piau used in the present experiment were maintained in incubators with constant running water and temperature around $24^{\circ} \mathrm{C}$. High temperatures, within a certain limit, have been shown to accelerate chorion rupture and consequent hatching (Woynarovich \& HorvátH 1980). The hatching of L. piau eggs occurred 21 hours after fertilization at a water temperature of $24^{\circ} \mathrm{C}$ or 504 hours-degree. These data were similar to those described by SATO et al. (2003) for other species of Leporinus at the same temperature: 477 hours-degree in L. elongatus and 512 hours-degree in L. taeniatus. In L. macrocephalus, Reynalte-Tataje et al. (2001) found a lower value, 324 hours-degree, however, with mean water temperature of $28.2^{\circ} \mathrm{C}$.

Studies on chromatophores as well as on eye and body pigmentation have been important in determining taxonomic characteristics used for species identification (MeIJIDE \& GUERREIRO 2000). Larvae of $L$. piau were transparent on the first day, retinal pigmentation initiated on the second day and completed only after the fourth day. Retinal pigmentation has been reported as variable: in Pseudoplatystoma coruscans (Agassiz, 1829) it spreads from the center to the periphery of the retina (SANTOS \& Godinho 1994) and in L. elongatus (SANTOS $\&$ GodinHo 1996) and Salminus brasiliensis (Curvier, 1817) (SANTOS $\&$ GodinHo 2002) it was uniform, similar to larvae of L. piau in the present study.

When the mouth opens, larvae have been seen to begin to need exogenous feeding (SATo et al. 2003) is a relationship between mouth opening and yolk sack absorption has been reported (LASKER et al. 1970). The period of yolk sack absorption can be variable in neotropical larvae (SANTOS \& GodinHO 2002). In larvae of $L$. piau the yolk sack was completely absorbed by the fourth day, when the mouth opened. This period coincided with a higher opening of the lumen and development of the digestive tract and enclosed organs, such as hepatopancreas, and was similar to the mean time observed in other species of Leporinus (NAKATANi et al. 2001, SANTOS \& GodinHO 1996).

The embryonic and larval development of L. piau followed patterns that have been reported in other Anostomidae (Santos \& Godinho 1996; Nakatani et al. 2001; Reynalte-Tataje et aI. 2001).

\section{AKNOWLEDGEMENTS}

We thank the Hydrology and Hatchery Station of Três Marias, Minas Gerais - CODEVASF for supplying the biological material, the biologists Geraldo Eustáquio Valente Padilha and Gilberto Nepobuceno Salvador for their assistance on the photographic recording, and to Dr. Robert J. Young for suggestions on the English version. The study was supported by grants from CNPq (No. 479733/01) and PROBIC- PUC Minas (No. 2002/04P).

\section{REFERENCES}

BlaXter, J.H.S. 1988. Eggs and Larvae, p. 17-48. In: W.S. HoAr \& D.J. Randall (Eds). Fish Physiology. New York, Academic Press, vol. 11A, 546p.

Britski, H.A.; Y. Sato \& A.B.S. Rosa. 1984. Manual de identificação de peixes da região de Três Marias: com chaves de identificação para os peixes da bacia do São Francisco. Brasília, Câmara dos Deputados, CODEVASF, 143p. Fowler, H.W. 1950. Os peixes de água doce do Brasil. Arquivos de Zoologia, São Paulo, 6 (2): 205-404.

Revista Brasileira de Zoologia 21 (1): 117-122, março 2004 
KuO, C.M.; Z.H.SHEHADEH; K.K. MiLISEN. 1973. A preliminary report on the development growth and survival of laboratory reared larvae of the grey mullet, Mugil cephalus L. Journal of Fish Biology, London, 5: 459-470.

Lasker, R.; H.M. Feder; G.H. Theilacher \& R.C. May. 1970. Feeding, growth and survival of Engraulis mordax larvae reared in the laborayory. Marine Biology, Berlin 5: 345-353.

Meijide, F.J. \& G.A. Guerreiro. 2000. Embryonic and larval development of a substrate-brooding cichlid Cichlasoma dimerus (Heckel, 1840) under laboratory conditions Journal of Zoology, London, 252: 481-493.

Morrison, C.M.; T. MiYAKe \& J.R. Wright JR. 2001. Histological study of the development of the embryo and early larva of Oreochromis niloticus (Pisces:Ciclidae) Journal of Morphology, New York, 247: 172-195.

Nakatani, K.; A.A. Agostinho; G. Baumgartner; A. Bialetzki; P.V. SANChes; M.C. Makrakis; C.S. PAVAnelli. 2001.Ovos e larvas de peixes de água doce: Desenvolvimento e manual de identificação. Maringá, EDUEM, 378p.

Reynalte-Tataje, D.; E. Zaniboni-Filho; B. Muelbert. 2001. Stages of the embryonic development of the piavuçu Leporinus macrocephalus (Garavello \& Britski, 1988). Acta Scientiarum, Maringá, 23 (4): 823-827.

SAnTos, J.E \& H.P. Godinho. 1994. Morfogênese e comportamentos larvais do surubim (Pseudoplatystoma coruscans Agassis, 1829) sob condições experimentais. Arquivo Brasileiro de Medicina Veterinária e Zootecnia, Belo Hori- zonte, 40 (2): 139-147.

. 1996. Larval ontogeny and swimming behaviour of the leporin fish Leporinus elongatus (Valenciennes, 1874) under experimental conditions. Arquivo Brasileiro de Medicina Veterinátria e Zootecnia, Belo Horizonte, 48 (1): 109-116. . 2002. Ontogenic events and swimming behavior of larvae of the characid fish Salminus brasiliensis (Curvier) (Characiformes, Characidae) under laboratory conditions. Revista Brasileira de Zoologia, Curitiba, 19 (1): 163-171. Sato, Y.; N. Fenerich-Verani; A.P.O. Nuñer; H.P. Godinho; J.R. Verani. 2003. Padrões reprodutivos de peixes da bacia do São Francisco, p. 224-268. In: H.P. GodinHo \& A.L. GodinHO (Eds). Águas, peixes e pescadores do São Francisco das Minas Gerais. Belo Horizonte, CNPq/PADCT, Editora PUC Minas, 440p.

Soares, A.C.; Y. Sato; N. Bazzoli; E. Rizzo \& R.M.A. Ferreira. 1996. Tamanho de primeira maturação sexual do Schizodon knerii e do Leporinus piau (Teleostei, Anostomidae) na represa de Três Marias, M.G. Arquivo Brasileiro de Medicina Veterinária e Zootecnia, Belo Horizonte, 48 (1): 47-54.

TAVARES, E.F. \& H.P. Godinho. 1994.Ciclo reprodutivo do piaugordura (Leporinus piau Fowler, 1941) da represa de Três Marias, Rio São Francisco. Revista Ceres, Viçosa, 41 (233): 28-35.

Woynarovich, E. \& L. Horváth. 1980. The artificial propagation of warm - water finfishes - manual of extensions. FAO Fisheries Techinical Paper, Rome, 201: 1-183.

Received in 27.VI.2003; accepted in 03.II.2004. 